\title{
Assessing the Water Quality of Cabugao Bay in Catanduanes Island, Luzon, Philippines
}

\author{
Ryan Paul Custodio Brillante*, Jimmy Tevar Masagca \\ College of Arts and Sciences, Catanduanes State University, Catanduanes, Philippines \\ Email address: \\ Apolgly121016@gmail.com (R. P. C. Brillante), jtibarmasagca@gmail.com (J. T. Masagca) \\ ${ }^{*}$ Corresponding author
}

\section{To cite this article:}

Ryan Paul Custodio Brillante, Jimmy Tevar Masagca. Assessing the Water Quality of Cabugao Bay in Catanduanes Island, Luzon, Philippines. Journal of Water Resources and Ocean Science. Vol. 7, No. 5, 2018, pp. 77-84. doi: 10.11648/j.wros.20180705.12

Received: August 22, 2018; Accepted: November 7, 2018; Published: January 28, 2019

\begin{abstract}
This paper assessed some physico-chemical parameters of Cabugao Bay in Catanduanes Island, Luzon, Philippines during November-December 2017 and January 2018, by evaluating seven quality parameters. Physical parameters included temperature, conductivity, and turbidity. Chemical parameters were $\mathrm{pH}$, chlorine, ammonia, and dissolved oxygen. Descriptive method of research was used through fieldwork survey. Six sampling sites were considered. Results showed that the temperature of the bay is within the standard set by the Department of Environment and Natural Resources (DENR) in 2016. Conductivity and turbidity of the water provided high values indicating human activity disturbances, presence of industries such as generators, oil storage, vulcanizing, automobile repair, and other maintenance ventures. The chemical characteristics of the bay have no severe signs. However, there are indications that some chemical substances are affected by human wastes, domestic wastes, agricultural wastes, and other natural disturbances to water quality considering that the dissolved oxygen exceeded the standards. Results imply for sustainable ecosystem-based management (EBM) by addressing fisheries activities, tourism and human activities. Future studies may include other parameters: silicate, mercury, phosphate, iron $(\mathrm{Fe})$, and other metallic substances; and studies on diurnal fluctuations of turbidity and determination of total solids, total organic matter, and sediment analysis throughout the bay.
\end{abstract}

Keywords: Water Quality, Cabugao Bay, Catanduanes Island, Luzon, Philippines

\section{Introduction}

The Philippine archipelago has more than 1,700 reef fish species and an estimated nine percent of global coral reef area (approximately $25,060 \mathrm{~km}^{2}$ ) [1]. With this scenario, the country is home to numerous aquatic and marine resources. However, the marine resources of the Philippines are also experiencing the highest level of anthropogenic and climatic threats [2]. The anthropogenic threats include fishing overcapacity; overfishing and destructive fishing practices; increased domestic, agricultural, and industrial runoff from a burgeoning population; poor land use; and increased sedimentation from forest deforestation and unregulated mining activities [3-5].

In addition, the use of the physico-chemical properties of water to assess water quality gives a good impression of the status, productivity and sustainability of such water body-- the Cabugao Bay in Catanduanes [6]. Changes in physical characteristics like temperature, transparency and chemical elements of water such as dissolved oxygen, chemical oxygen demand, nitrate and phosphate provide valuable information on the quality of water, the source of the variations and their impacts on the functions and biodiversity of a body of water [7]. On the other hand, seasonal changes in fish community structure in mangroves were generally considered to be affected by factors such as salinity, temperature, turbidity, water depth, and vegetation in the environment [8-11].

Catanduanes is a small island in the Pacific which is one of the 7,100 islands comprising the Philippine archipelago. It lies between $13.5^{\circ}$ and $14.1^{\circ} \mathrm{N}$ Latitude and extends from $124.0^{\circ}$ to $124.5^{\circ} \mathrm{E}$ Longitude. Being along the Pacific side of the Philippines, it is surrounded by coastal waters joining the vast Pacific. As such, its waters are home to a large number of aquatic life. This study was carried out in one of the 
island's small body of water known as Cabugao Bay. It is a small body of water which serves as the island's vital source of fishes. It is also perceived to be a productive ecosystem wherein the coastal municipalities of Virac and Bato, to some extent, depend for protein from fish; and fishing is the source

of livelihood of a great number of the population living in the coastal area. The bay also serves for the propagation and growth of fish and other aquatic resources which are intended for commercial and sustenance of fishing. People use it as well for recreation or similar activities as there are a number of beach resorts along the area. Hence, the beaches along the coast of Cabugao Bay cater for fisheries activities, entertainment, tourism, and other human activities.

The study assessed the water quality of Cabugao Bay in terms of temperature, conductivity, turbidity, $\mathrm{pH}$, chlorine, ammonia, and dissolved oxygen. The output of this study provides the status of water quality in Cabugao Bay in Catanduanes Island, Luzon, Philippines.

\section{Method}

The map of Cabugao Bay (Figure 1) shows the location of the six study sites. Study sites 1 (Batalay) and 2 (Guinobatan) are far from the shore while study sites 3 (San Vicente-Ibong
Sapa), 4 (Francia-rawis-Santa Cruz) and 5 (Salvacion-San Pablo) are close to the shore. Study sites 2 (Guinobatan) and 6 (Palnab-Pajo-Antipolo) are influenced at the entrance of rivers. These study sites cover the coastal area of Cabugao Bay stretching to the municipalities of Bato and Virac.

Water samples used in determining the physico-chemical characteristics of Cabugao Bay were collected from the six study sites established in the bay. Samples were collected during the months of November and December 2017, and January 2018. Collection of water samples was done twice in November 2017 and January 2018. In December 2017, the collection was done once due to heavy rains and weather disturbances causing rough seas which made it impossible for the researcher to gather the water samples. Physical data collections were made at each study site through the water column using Amphibia 2 Instrument. Seven parameters generated by this gadget were used in determining water quality, namely: temperature, conductivity, turbidity, $\mathrm{pH}$, chlorine, ammonia, and dissolved oxygen. The quality of water was assessed in accordance with the Philippine DENR standards issued in 2016. Simple frequency count and arithmetic mean were used in the analysis of data. Graphical analysis of data was also applied.

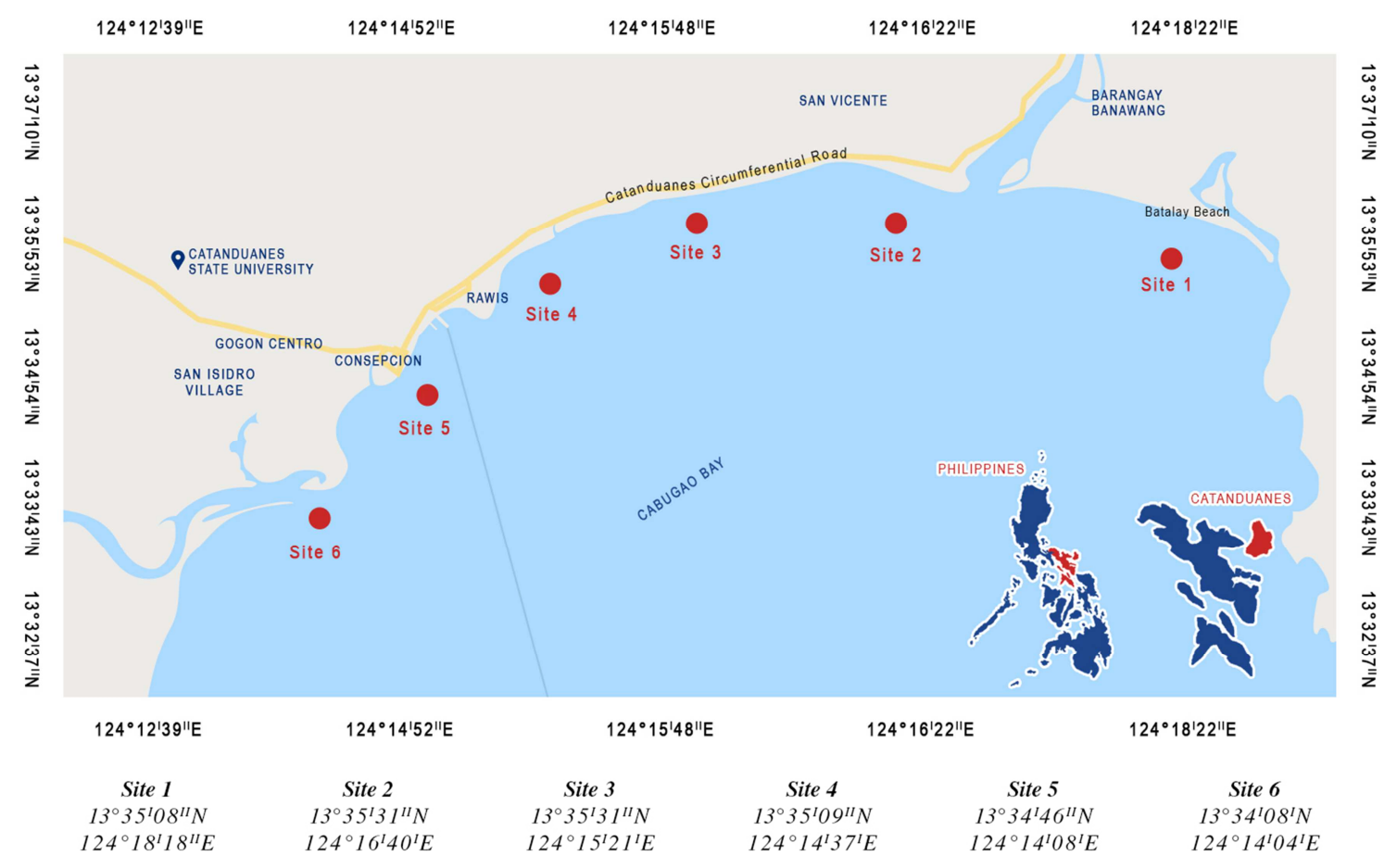

Figure 1. Map of Cabugao Bay showing the six study sites.

\section{Result}

\subsection{Physical Parameters}

Table 1 summarizes the mean values of the physical parameters of Cabugao Bay in comparison with the standard set by the Philippine DENR per Administrative Order (AO) No. 2016-08 dated May 24, 2016. Cabugao Bay is classified as Class SC-a fishery water for the propagation and growth of fish and other aquatic resources; and intended for commercial and sustenance fishing, for boating, or similar activities. 
Table 1. Summary of data for temperature, conductivity, and turbidity examined using amphibia 2 for water quality determination of Cabugao Bay by study site.

\begin{tabular}{lllllll}
\hline \multirow{2}{*}{ Parameters } & Study Site & & & \\
\cline { 2 - 5 } & $\mathbf{1}$ & $\mathbf{2}$ & $\mathbf{3}$ & $\mathbf{4}$ & $\mathbf{5}$ & $\mathbf{6}$ \\
\hline Temperature & 27.64 & 27.51 & 27.89 & 28.14 & 26.69 \\
Conductivity (Sp Cond uS/cm) & 30141.02 & 7464.25 & 27030.01 & 26786.08 & 34140.24 \\
Turbidity (Turb Dig NTU) & 18.75 & 37.42 & 33.22 & 8.64 & 14361.32 & 27.34 \\
\hline
\end{tabular}

Legend:

Study Site 1 - Batalay Coastal Waters

Study Site 2 - Guinobatan Coastal Waters

Study Site 3 - San Vicente-Ibong Sapa Coastal Waters

Study Site 4-Francia-Rawis-Sta. Cruz Coastal waters

Study Site 5 - Salvacion-San Pablo Coastal Waters

Study Site 6-Palnab-Pajo-Antipolo Coastal Waters

Graphical analysis of the result on physical parameters of water quality assessed for conductivity and turbidity are as follows:

\section{Temperature}
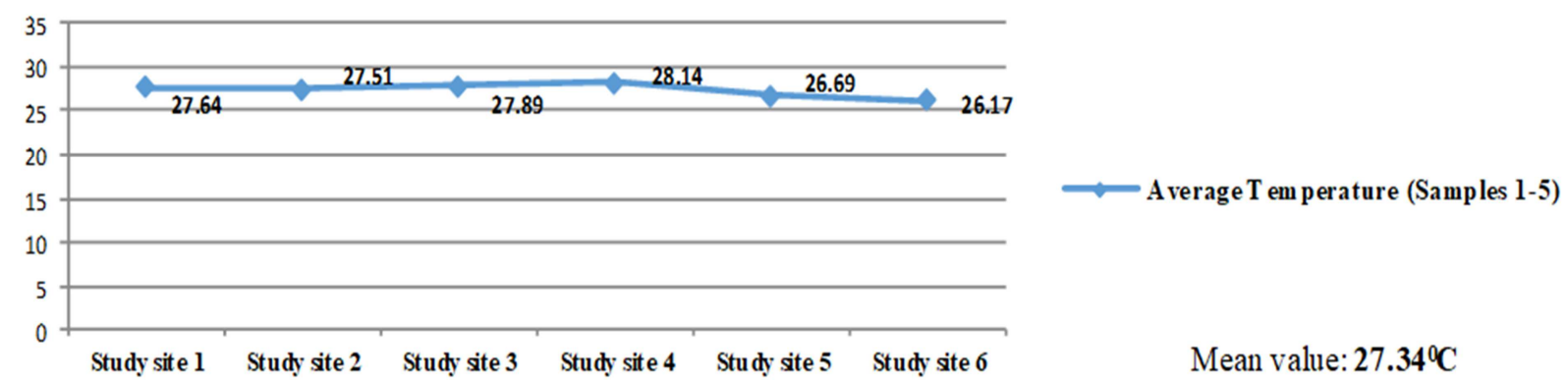

Figure 2. Temperature of Cabugao Bay by study site during the period of the study.

\section{Con ductivity}

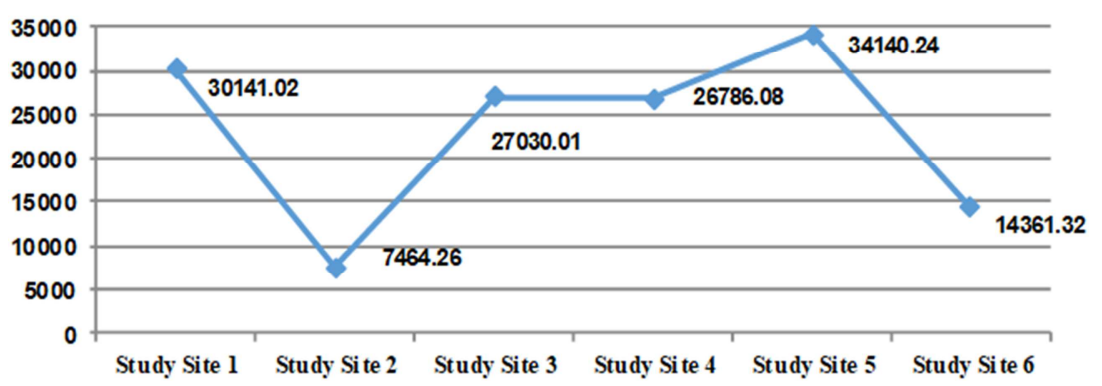

Mean value: $27.34^{\circ} \mathrm{C}$

Figure 3. Conductivity of Cabugao Bay by study site during the period of the study.

Turbidity

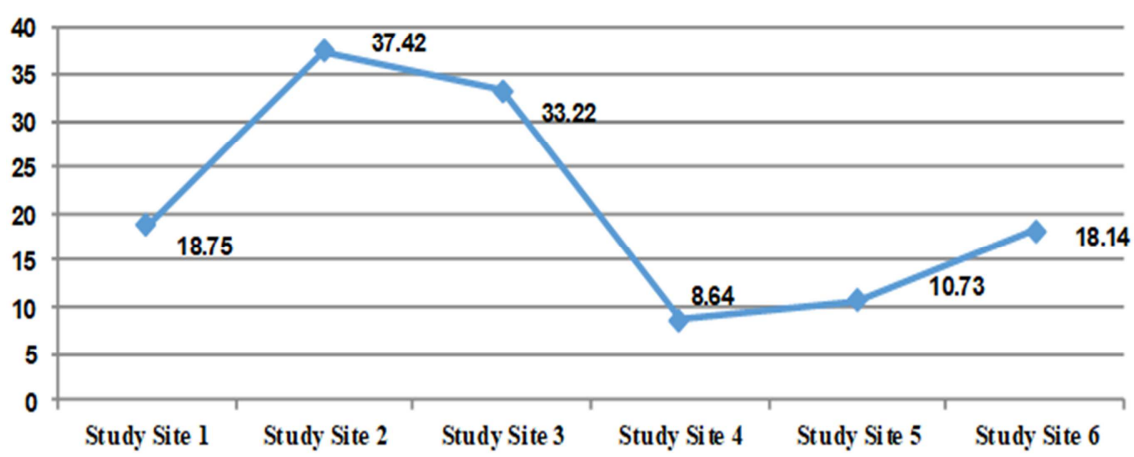

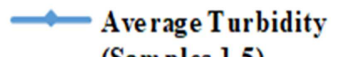

(Samples 1-5)

Mean value: $\mathbf{2 1 . 1 5}$

Figure 4. Turbidity of Cabugao Bay by study site during the period of the study。 


\subsection{Chemical Parameters}

The chemical parameters of Cabugao Bay were determined in terms of $\mathrm{pH}$, chlorine, ammonia, and dissolved oxygen. Table 2 summarizes the analysis of data by study site, while Table 3 shows the standard set by Philippine DENR (2016) for chemical parameters of water in the bay.

Table 2. Summary of Data for $\mathrm{pH}$, chlorine, ammonia, and dissolved oxygen examined using amphibia 2 for water quality determination of Cabugao Bay by study site.

\begin{tabular}{|c|c|c|c|c|c|c|c|}
\hline \multirow{2}{*}{ Parameters } & \multicolumn{6}{|c|}{ Study Site } & \multirow{2}{*}{ Mean } \\
\hline & 1 & 2 & 3 & 4 & 5 & 6 & \\
\hline $\mathrm{Ph}$ & 8.21 & 8.08 & 7.99 & 8.36 & 8.55 & 8.60 & 8.30 \\
\hline Chlorine $(\mathrm{Cl} \mathrm{mg} / \mathrm{L})$ & 2934.72 & 1861.40 & 3110.80 & 3288.04 & 1900.62 & 1696.10 & 2465.28 \\
\hline Ammonia $\left(\mathrm{NH}_{3} \mathrm{mg} / \mathrm{L}-\mathrm{N}\right)$ & 7.64 & 7.39 & 9.69 & 8.92 & 8.56 & 9.14 & 8.56 \\
\hline Dissolved Oxygen (HDO mg/I) & 7.72 & 7.83 & 6.48 & 8.02 & 8.23 & 8.62 & 7.82 \\
\hline
\end{tabular}

\section{Legend:}

Study Site 1 - Batalay Coastal Waters

Study Site 2 - Guinobatan Coastal Waters

Study Site 3 - San Vicente-Ibong Sapa Coastal Waters

Study Site 4 - Francia-Rawis-Sta. Cruz Coastal waters

Study Site 5 - Salvacion-San Pablo Coastal Waters

Study Site 6-Palnab-Pajo-Antipolo Coastal Waters

Table 3. Chemical Parameters of Cabugao Bay and the standard set by Philippine DENR for class SC body of water per Administrative Order No. 2016-08.

\begin{tabular}{llll}
\hline Chemical Characteristics & Mean Value & Standard Set by the Philippines DENR (2016) & Interpretation \\
\hline $\mathrm{pH}$ & 8.30 & $6.0-9.0$ & Within the standard \\
Chlorine & 2465.28 & - & No standard set \\
Ammonia & 8.56 & 10 & Within the standard \\
Dissolved oxygen & 7.82 & 5 & Not within the standard \\
\hline
\end{tabular}

Graphical analysis of the result on chemical parameters of water quality assessed for chlorine, ammonia, and dissolved oxygen are as follows:

\section{pH}

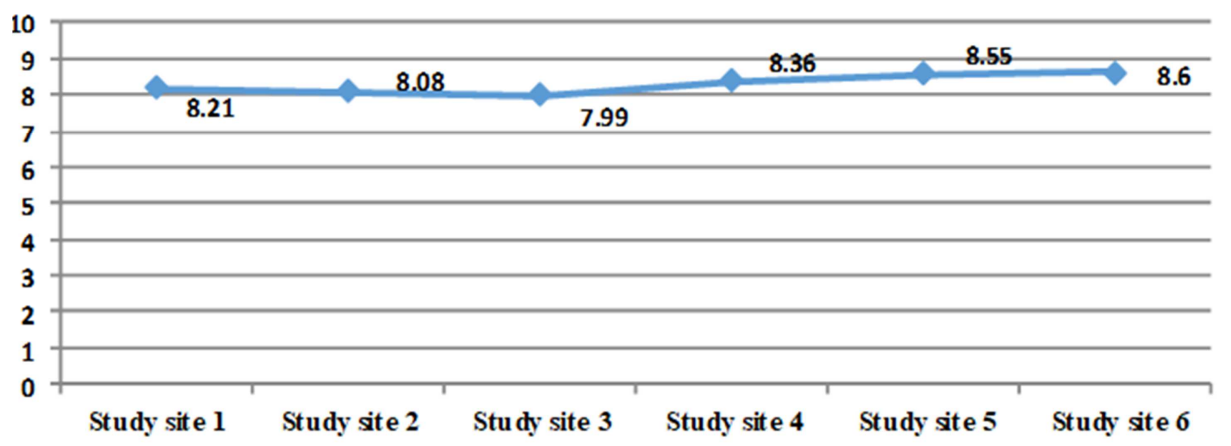

Figure 5. pH of Cabugao Bay by study site during the period of the study.

\section{Chlorine}

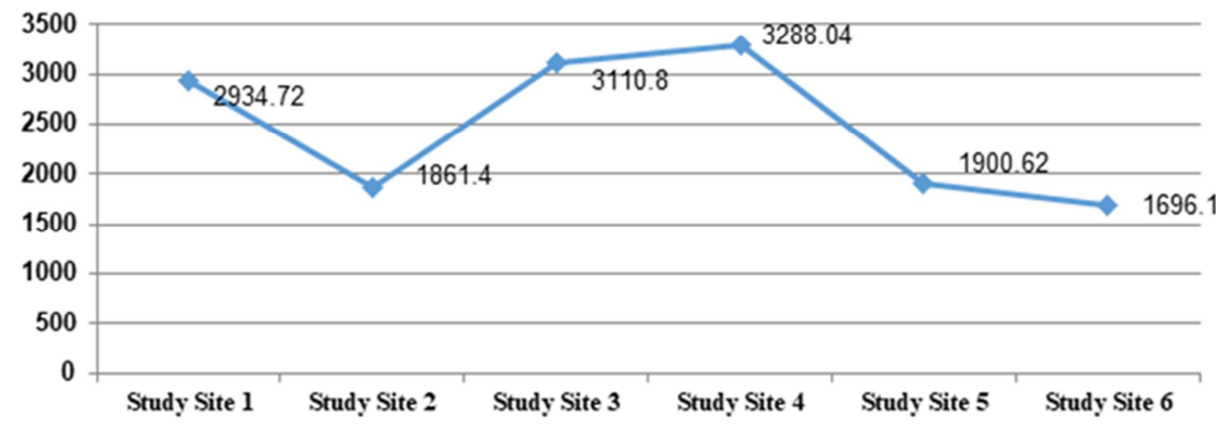

Figure 6. Chlorine Content of Cabugao Bay by study site during the period of the study. 
Am monia

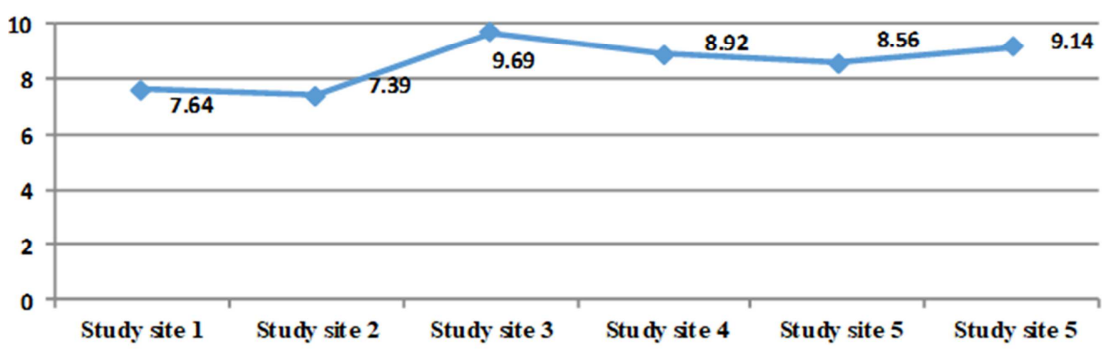

$\longrightarrow$ Averag e Nitrate ( $\mathrm{S}$ am ples $1-5)$

Mean value: $\mathbf{8 . 5 6}$

Figure 7. Ammonia Content of Cabugao Bay by study site during the period of the study.

\section{Dis solved Oxygen}

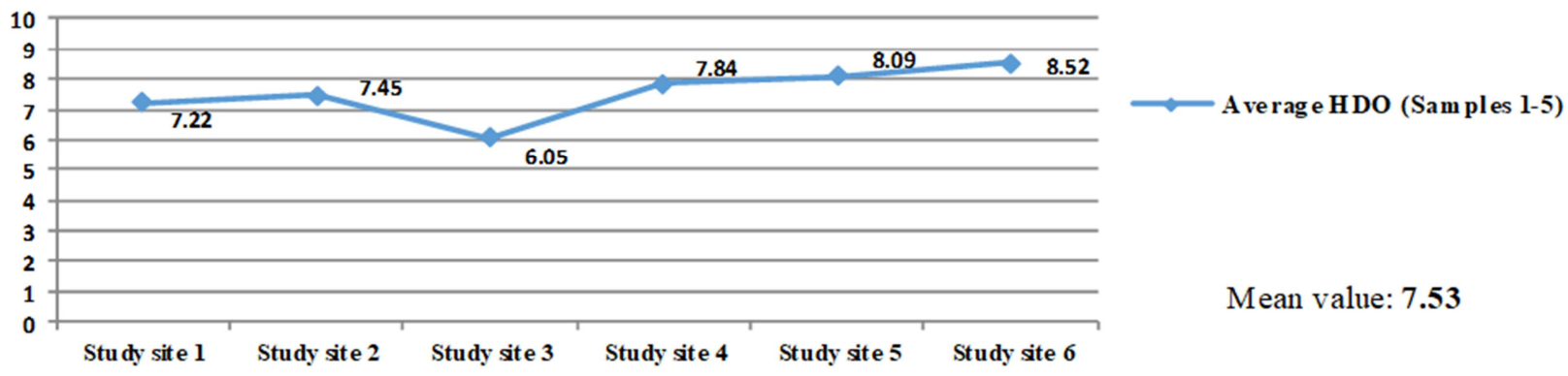

Figure 8. Dissolved Oxygen in Cabugao Bay by study site during the period of the study.

\section{Discussion}

\subsection{Physical Parameters}

\subsubsection{Temperature}

The temperature ranged from $26.17^{\circ} \mathrm{C}$ to $28.14^{\circ} \mathrm{C}$ with a mean value of $27.34^{\circ} \mathrm{C}$ (Table 1, Figure 2). It appears that the lowest was recorded for the data gathered in study site 6 , with river inputs from Pajo-Santo Domingo River while the highest was in study site 4 , where water discharges from large food businesses, three hospitals and eateries or beer shops are numerous. These results can be analyzed in terms of the dynamic changes taking place in sea water system which normalizes the temperature. Temperature cannot change abruptly due to wind, current, or tide. If there will be an increase in temperature, it could be attributed to the pressure of navigational activity and/or entry of sewage from industries as observed in study sites 4 and 5. Result of temperature data analysis of Cabugao Bay is supported by a study conducted in Palk Bay, Southeast Coast of India with a temperature variation from $28^{\circ} \mathrm{C}-32.50^{\circ} \mathrm{C}$ to $27.50-32.0^{\circ} \mathrm{C}$ [12].

\subsubsection{Conductivity}

The analysis of data on conductivity revealed a mean value of 23320.49. At present there is no water quality index associated with conductivity that even Philippine DENR (2016) has no standard set for water conductivity. Abrupt changes in conductivity may indicate that wastes are diverted into the bay from adjacent rivers. As shown in Figure 3, the highest conductivity value was recorded for study site 5 (Salvacion-San Pablo coastal waters). Conductivity can be used as a measure of total dissolved solids (TDS). It can be inferred that study site 5 being in the center of the municipality of Virac, the capital town of the Island, total dissolved solid reading is high.

The preceding results could be connected to the observation that the number of fish species decreases in water with high conductivity [13]. The ranges of electrical conductivity and TDS values support productive fisheries. These two parameters could be used as morpho-edaphic index to estimate potential fish yields [14].

High conductivity values recorded for the data gathered may also have some bearing on environmental problems, including water quality decline and pollution which have exacerbated the reduction in fisheries productivity [15], [16]. In addition, it was reported that the declining fish catch in the Philippines can be attributed to the conversion of mangroves into fish ponds and overexploitation of coastal resources in coastal areas [17]. In a similar situation, human induced activities such as overfishing and continuing coastal forests clearings may be attributed to poor reproduction and development of marine life [3]. These human activities affect the marine ecosystem and a threat to the sustainability of marine life [18].

\subsubsection{Turbidity}

This is a measure of cloudiness in water. Turbidity can be caused by soil erosion, waste discharge, runoff, bottom feeders and algal growth. Turbidity readings ranged from 1.27 to $52.83 \mathrm{dig}$ NTU and an average of $21.15 \mathrm{dig}$ NTU (Table 1; Figure 4). Be it mentioned that there is no standard set for turbidity (Philippine DENR, 2016).

Study site 2 (Guinobatan coastal waters), as shown in Figure 4, has the highest recorded turbidity value of 37.42 followed by study site 3 (San Vicente-Ibong Sapa coastal 
waters) with a value of 33.22. The color and total suspended solids in the sea water provide the visual quality of the water; the higher concentration signifies highly turbid water.

Color concentration of $50 \mathrm{mg} / \mathrm{L}$ and beyond signals a turbid water which can be caused by natural disturbance such as increased sedimentation during rainy season or anthropogenic disturbance such as quarry activities downstream of the rivers as in the Bato-Guinobatan River area. Study site 3 (San Vicente-Ibong Sapa coastal waters) is positioned close to the power plants of the First Catanduanes Electric Cooperative (FICELCO) and National Power Corporation (NAPOCOR) where contamination is brought by power generators causing sedimentation into the sea.

However, it is noticeable that the turbidity of Cabugao Bay was recorded the lowest in study site 4 (Francia-Rawis-Sta. Cruz coastal waters). This could be explained that because of the dynamic activities in the bay by the time that the dissolved solids would reach the next study site such were already diffused; hence, in study site 4 dissolved solids have dissipated. The water is clear again. Results on the turbidity of water samples obtained in Cabugao Bay during the study period are supported by the reports of other researchers [19]. They reported that surface sediments found in Calape Bay in Bohol, Central Philippines were mainly composed of sand and gravel. During the conduct of the study, road construction projects in Catanduanes are on-going. Thus, sand quarrying activities could not be avoided.

\subsection{Chemical Parameters}

\subsection{1. $\mathrm{pH}$}

The water quality of Cabugao Bay in terms of potential hydrogen or how much hydrogen is mixed with the water shows that $\mathrm{pH}$ value per study site (Table 2; Figure 5) is within the standard of 6.0-9.0 (Philippine DENR, 2016). It shows, however, that since the $\mathrm{pH}$ values recorded are all above 7, the coastal water in Cabugao Bay is alkaline [20]. The slight fluctuations or changes in values can be analyzed as insignificant changes which will cause little or no effect to the respiration and other metabolism processes of fishes in the bay.

This result is similar to the $\mathrm{pH}$ values reported by other researchers who assessed the characteristics of Mediterranean Sea water in the vicinity of Sidikerir Region, west of Alexandria, Egypt [21]. They concluded that at $\mathrm{pH}$ range of 8.03-8.53, the sea water was slightly alkaline. A similar study conducted in Pampanga River along Barangay Buas in Candaba, Pampanga also reported that the $\mathrm{pH}$ value of the water in this river is within the 6.0-9.0 standard set by the DENR [22]. Although the present study is on sea water and the previous related study is on fresh water yet similarity exists using the standard. The water quality in Palk Bay, Southeast Coast of India also reported $\mathrm{pH}$ values ranging from 7.95-8.35 [12]. It shows as well that it is within the standard.

\subsubsection{Chlorine}

Hypochlorite reacts rapidly with the bromide ion in seawater to form hypobromous acid and hypobromite. The mean value of $2465.28 \mathrm{mg} / \mathrm{L}$, as shown in Table 2 and in Figure 6, may be accorded to a study conducted chlorine reactions with seawater [23]. It was reported that the occurrence of "residual bromine" are manifestations of physiologically active substances formed on chlorinating seawater. The biocidal concentrations of "chlorine" for marine organisms would not necessarily be the same as those reported for freshwater organisms.

As shown in Figure 6, study site 4 (Francia-Rawis-Sta. Cruz coastal waters) registered the highest reading for chlorine, 3288.04, followed by study site 3 (San VicenteIbong Sapa coastal waters), 3110.8. These study sites are adjacent which could have been the reason why the values are close. Both sites are in the coastal areas where there are power plants, beach resorts, and hospitals where active human activities are occurring. There is no established standard for chlorine applicable to Class SC of body of water (Philippine DENR, 2016) as reflected in Table 3. Chlorine is a greenish-yellow gas that dissolves easily in water. It has a pungent, noxious odor that some people can smell at concentrations above 0.3 parts per million. Free chlorine (chlorine gas dissolved in water) is toxic to fish and aquatic organisms, even in very small amounts. However, its dangers are relatively short-lived compared to the dangers of most other highly poisonous substances.

That is because chlorine reacts quickly with other substances in water or it dissipates as a gas into the atmosphere.

Another study reported that the inhibitory effects of high temperature and residual chlorine on growth and photosynthesis of Chlamydomonas sp. and Skeletonema costatum [24]. It leads to the conclusion that the high temperature of, and residual chlorine in effluents from a power plant discharging into the open sea, should not cause great damage to marine phytoplankton in that area.

\subsubsection{Ammonia}

Ammonia can be present in water in two forms, either ammonium hydroxide $\left(\mathrm{NH}_{3}\right)$ or as ammonia ion $\left(\mathrm{NH}_{4}\right)$. When the $\mathrm{pH}$ of water is less than 7 the ammonia is present as ammonium ion. As $\mathrm{pH}$ increases above 7, more of the ammonia is present as ammonium hydroxide $\left(\mathrm{NH}_{3}\right)$ [25] Since $\mathrm{pH}$ values obtained in the different study sites and sampling schedule were more than $7, \mathrm{NH}_{3}$ values were analyzed for this purpose. The mean value obtained for ammonia is 8.56 (Table 2; Figure 7). This value is within the standard set by Philippine DENR (2016) (see Table 3) which means that Cabugao is fit for humans and other bioresources dependent on the bay for existence.

\subsubsection{Dissolved Oxygen}

The mean value of HDO $\mathrm{mg} / \mathrm{L}$ from the water samples obtained in Cabugao Bay is 7.53 (see Table 2; Figure 8). The standard value set by Philippine DENR (2016) is 5 (Table 3). It shows therefore that dissolved oxygen in the waters of Cabugao Bay is not within the standard rather it exceeded the standard value. DENR (2016) regulates that the maximum 
increase must be only up to 10 percent and that it will not cause any risk to human health and the environment. However, in this case 10 percent increase of 5 is 0.5 which means at least the value of dissolved oxygen is 5.5. The value of 7.53 is more than the limit.

Much of the dissolved oxygen (DO) in seawater comes from the atmosphere. Algae and rooted aquatic plants also deliver oxygen to water through photosynthesis. Changes in DO levels are due to the build-up of organic wastes. Decay of organic wastes consumes oxygen and is often concentrated in summer. Study site 6 recorded the highest dissolved oxygen, 8.52 , in the waters of Cabugao Bay while the lowest was in study site $3,6.05$. It shows that it exceeded the standard of 5.0. As mentioned earlier, changes in DO levels are due to the build-up of organic wastes. Decay of organic wastes consumes oxygen and is often concentrated in summer. It is inferred therefore that these are due to wastes brought by many human activities affecting the waters of Cabugao Bay.

The physico-chemical parameters used as indicators of the Cabugao Bay ecosystem health can be potentially linked directly to socio-economic indicators such as access to safe water, environmental or watershed protection expenditures, withdrawal of surface water, and domestic consumption of water per capita. These indicators and could be further reinforced by providing a general description of the prevailing water quality of the rivers and the monitoring study sites, and can be done through the calculation of water quality index.

Based on the parameters assessed in previous studies, phosphates, and total suspended solids were often observed to exceed the standards. Among the common sources of phosphates and nitrates in waters are wastewater and septic effluents, detergents, fertilizers, soil run-off, industrial discharges, and synthetic materials which contain organophosphates, such as insecticides. It is a limiting nutrient needed for the growth of all plants--aquatic plants and algae alike, if too much nutrients are present in the water the algae and weeds will grow rapidly, may choke the waterway, and use up large amounts of precious oxygen and it could result to the death of fishes and other aquatic organisms.

\section{Conclusion}

Temperature, conductivity, and turbidity of the water in Cabugao Bay were the physical parameters assessed in this study. The temperature of the bay during the study period is within the standard set by Philippine DENR (2016). Conductivity and turbidity of the water provide high values indicating human activity disturbances, presence of industries such as generators, oil storage, vulcanizing, and other automobile repair and maintenance ventures. The chemical parameters assessed showed no alarming signs for Cabugao Bay; however, there are some indications that some chemical substances are affected by human wastes, domestic wastes, agricultural wastes, and other natural disturbances to water quality. This is indicated by dissolved oxygen which exceeded the standard.

\section{References}

[1] Spalding, M. D., Ravilious, C., \& Green, E. P. (2001) World Atlas of Coral Reefs. Berkeley: University of California Press.

[2] Burke, L., Reytar, K., Spalding, M., \& Perry, A. L. (2012) Reefs at Risk Revisited in the Coral Triangle. World Resources Institute, The Nature Conservancy, WorldFish Center, International Coral Reef action Network, UNEP World Conservation Monitoring Center and Global Coral Reef Monitoring Network. Washington, D. C.

[3] Aldea, K. Q., Morales, M. I., Araojo, A. E., \& Masagca, J. T. (2015) Biodiversity in the Kuroshio region: Challenges and trends in the upstream. Kuroshio Science, 9 (1), 45-56, 2015.

[4] Cabral, R. B., Alino, P. M., Balingit, A. C. M., Alino, C. M., Arceo, H. O., Nanola, C. L. Jr., \& Geronimo, R. C. (2014) Marine Protected Area Support Network (MSN). Philippine Science Letters, 7 (2), 300-308.

[5] Geronimo, R. C. \& Cabral, R. B. (2014) Fish production in the coral triangle: Status, trends, and challenges. In Asian Development Bank (2014), Economics of Fisheries and Aquaculture in the Coral Triangle. Asian Development Bank, Mandaluyong City, Philippines.

[6] Djukic, N., Maletin, S., Pujin, V., Ivanc, A., \& Milajonovic, B. (1994) Ecological assessment of water quality of Tiszeby physico-chemical and biological parameters. Tisca Szeged, 28: 37-40.

[7] Wetzel, R. G. (2000). Freshwater ecology: changes requirements, and future demands. Limnology, 1:3-9.

[8] Tsai, C. H., Wang, Y. K., Tsai, S. T., \& Wu, S. H. (2015) Seasonal and diel changes of the fish assemblage employing the fyke nets in a subtopical mangrove estuary of Puzih River, Taiwan. Journal of Marine Science and Technology, 23 (1): 106-116. DOI: 10.6119/JMST-014-0110-3.

[9] Tzeng, W. N., Wang, Y. T., \& Chang, C. W. (2002) Spatial and temporal variations of the estuarine larval fish community on the west coast of Taiwan. Marine and Freshwater Research, 53: 419-430.

[10] Huxham, M., Kimani, E., \& Augley, J. (2004) Mangrove fish: a comparison of community structure between forested and cleared habitats. Estuarine, Coastal and Shelf Science, 60: 637-647.

[11] Crona, B. I. \& Ronnback, P. (2007) Community structure and temporal variability of juvenile fish assemblages in natural and replanted mangroves, Sonneratiaalba Sm., of Gazi Bay, Kenya. Estuarine, Coastal and Shelf Science, 74: 44-52.

[12] Sridhar, R., Thangaradjou, T., Kumar, S. S., \& Kannan, L. (2006) Water quality and phytoplankton characteristics in the Palk Bay, Southeast Coast of India. Journal of Environmental Biology, 27 (3), 561-566.

[13] Dumont, H. J. (1999) The species richness of reservoir plankton and the effect of reservoirs on plankton dispersal (with particular emphasis on rotifers and cladocerans). In Tundisi, J. G., Straskraba, M. (eds.) Theoretical reservoir ecology and its application, IIE, Backhuys Publishers, Brazilian Academy of Science, 477-491. 
[14] Jenkins, R. M. (1982) The morphoadaphic index and reservoir fish production, Transactions of the American Fisheries Society, 111: 133-140.

[15] Shannon, D. (2002) The future of municipal fisheries in the Philippines: Does the Philippine fisheries code do enough? Pacific Rim Law and Policy Journal, 11 (3), 717-743.

[16] White, A. T. et al. (2000) Management of fisheries, coastal resources and the coastal environment in the Philippines: Policy, legal and institutional framework 11. ICLARM, Working Paper, No. 5, 1999.

[17] Vedra, S. A. et al. (2017) The way forward to sustaining coastal fisheries through implementing the acquasilviculture program. Int. J. Hum. Capital Urban Management, 2 (3): 203210. DOI: 10.22034/ijhcum.2017.02.03.004.

[18] Mohammed, B., Tewabe, D., Zelalem, W., \& Melaku, A. (2016) Physical, chemical, biological properties and fish species type of Geray reservoir, -W/Gojjam Zone, Ethiopia. International Journal of Acquaculture and Fishery Sciences, 2 (1): 008-011. DOI: 10.17352/2455-8400.000012.

[19] Argente, F. A. T., Palla, H. P., Narido, C. I., Celedonio, M. A., \& Dy, D. T. (2013) Spatial distribution of organic matter in the surface sediments of Calape Bay, Bohol, Central Philippines. Philippine Journal of Science, 142 (2): 133-141.
[20] "Water" (2013) Retrieved from www.deq.state.ok.us/factsheets/general/bluegreen algae.web.pdf.

[21] Abdel-Halim, A. M. \& Aly-Eldeen, M. A. (2016) Characteristics of Mediterranean Sea water in vicinity of Sidikerir Region, west of Alexandria, Egypt. Egyptian Journal of Aquatic Research. Retrieved from http://dx.doi.org.10.1016/j.cjar. 2016.05.002.

[22] Arbotante, C., Bandao, J., De Leon, A., De Leon, C., Janairo, Z., Lapuz, J., Manaloto, N. B., Nacpil, A., \& Salunga, F. (2015) Water quality in Pampanga River along Barangay Buas in Candaba, Pampanga. Proceedings of the DLSU Research Congress, Volume 3.

[23] Eppley, R. M. \& Williams, P. M. (1976) Chlorine reactions with seawater constituents and the inhibition of photosynthesis of natural marine phytoplankton. Estuarine and Coastal Marine Science, 4 (2), 147-161.

[24] Hirayama, K. \& Hirano, R. (1970) Influence of high temperature and residual chlorine on marine phytoplankton. Marine Biology, 7 (3), 205-213.

[25] "Ammonia in Water" (2017) Retrieved from www.purewateroccasional.net/wti.ammonia.html. 